\title{
PEMANFAATAN FUNGSI ANTI OKSIDAN GAMBIR (Uncaria gambir) SEBAGAI HEPATOPROTEKTOR
}

\author{
Zulkarnain Edward \\ Bagian Biokimia Fakultas Kedokteran Universitas Andalas
}

\begin{abstract}
The aim of the research is to find out the effect of the hepatoprotector from gambier to some rats animal contaminated by carbon tetrachloride $\left(\mathrm{CCl}_{4}\right)$. The research was done in Biochemistry laboratory Medical Faculty Andalas University Padang applied to 12 galur wistar rats species in about \pm 2 months ages with 170-200 g weight, which are separated into 3 groups (clusters). They are cluster in negative control, in positive control $\left(\mathrm{CCl}_{4} 2 \mathrm{mg} / \mathrm{kgBB}\right.$ inductions), and treated cluster $\left(\mathrm{CCl}_{4}\right.$ inductions and $10 \mathrm{mg} / \mathrm{kgBB}$ gambier given). Statistically analyzed the data by one way Anova test with $95 \%$ confidence of degree, the result of the research are pointed to the rate of MDA serum level which is $1.08 \pm 0.12 \mathrm{nmol} / \mathrm{mL}$ for the cluster in negative control, $4.07 \pm 0.45 \mathrm{nmol} / \mathrm{mL}$ for positive control cluster, and $3.28 \pm 0.46 \mathrm{nmol} / \mathrm{mL}$ for treated cluster showed the significant differences between the 3 clusters. The rates of MDA lever level to the cluster in negative control is about $1.80 \pm$ $0.30 \mathrm{nmol} / \mathrm{mL}$, in positive control is about $4.55 \pm 0.56 \mathrm{nmol} / \mathrm{mL}$, and the treated cluster is about $3.92 \pm$ $0.22 \mathrm{nmol} / \mathrm{mL}$, from the 3 clusters above shows that there is only the positive control and the treated control has no meaning of purpose. It concluded that the $\mathrm{CCl}_{4}$ has the hepatotoxite effect with gambier could be functionated as the hepatoprotector.
\end{abstract}

Key words : gambier, $\mathrm{CCl}_{4}$, hepatoprotector, $\mathrm{MDA}$ 


\section{DAFTAR PUSTAKA}

1. N. Nazar. Gambir Budidaya, pengolahan dan prospek diversifikasinya, Padang, Yayasan hutanku, 2000.

2. Y. Zasshi, Pharmacological action of Gambir, The Journal of Japanese History of Pharmacy, 40(1): 29-33, (2005).

3. T. Okuda, 26-Antioxidant in Herbs: Polyphenols, Antioxidant Food Suplements in Human Health, 393-410, (1999).

4. E. Yerizel, Pengaruh katekin teh hijau (Camelia sinensis) terhadap maondialdehid (MDA) darah dan MDA hepar tikus, Jurnal Penelitian Andalas, 14(37): (2002).

5. R. Pambayun, M. Garjito, S. Sudarmadji, K. Rahayu, Kuwanto, Kandungan fenol dan sifat antibakteri dari berbagai jenis ekstrak produk gambir (Uncaria gambir Roxb), Majalah Farmasi Indonesia, 18(3): 141-146, (2007).

6. E. Hayani, Analisis kadar katekin dari gambir dengan berbagai metode, Buletin Teknik Pertanian, 8(1), (2003).

7. Ali. M, Peranan radikal bebas pada patogenesa kerusakan hepar, Kumpulan makalah seminar dan lokakarya radikal bebas dan patogenesa penyakit, Malang, 13-15 Maret 1997.

8. R. A. Greenwald, Current approaches to the developments of oxygen radicals scavengers drug of today, 26: 299, (1990).

9. S. Syahbuddin, Peran radikal bebas dan anti oksidan pada proses penuaan dan diabetes melitus, Simposium pengaruh radikal bebas terhadap proses penuaan, Padang, 2 September 2000.

10. G. C. Cochrane, Cellular injury by oxydant, Am.J.Med, (1991).

11. G. Revila, Daya proteksi vitamin $\mathrm{C}$ terhadap radikal bebas yang ditimbulkan oleh karbontetraklorida $\left(\mathrm{CCl}_{4}\right)$ pada tikus ditinjau dari kadar malondialdehid (MDA) hepar. Jurnal Penelitian Andalas, 14(37): (2002). 